\title{
The Development of Indonesian Syntactic of Role Children Severe Hearing Impairment Preschool Age
}

\author{
Rahayu Pujiastuti \\ Universitas PGRI Adi Buana Surabaya \\ Surabaya, Indonesia \\ rahayu_pujiastuti@unipasby.ac.id
}

\begin{abstract}
Aim of this study to describe the development of Indonesian syntactic role of language children severe hearing impairment of preschool age. This study was conducted longitudinally on three subjects. The subject is children with severe hearing impairment preschool age $(5 ; 0)$ who go on group A TKLB-B (nursery school of students with special needs) as well as used the first language in the form of the language of Indonesia. The data used is the speech of research subjects that can give information the role of syntactic of Indonesian language. Speech in this study is a sentence as well as a word or syllable referred to as a sentence. In addition, data is taken when the child in the class, at home, or playing. Data collection uses four techniques, namely observation, fishing, logging, and recording. Data were analyzed with three techniques, namely sort, reverse, and connect techniques. Based on the results of data analysis found (1) the development or sequence of syntactic role acquisition of Indonesian children severe hearing impairment of preschool age describes his cognitive development include (a) $P$ means 'identifier', (b) $\mathbf{S}$ means 'experience', (c) $\mathbf{S}$ means 'actor', (d) $\mathbf{P}$ means 'action', (e) $\mathbf{P}$ means 'situation', (f) $\mathbf{O}$ means 'sufferer', (h) $\mathbf{P}$ means 'existence/place', (h) $\mathbf{K}$ means 'existence/place', (i) P means 'quantity', (j) Pel means 'sufferer'; (2) there is a deviation in the development of the syntactic role of Indonesian children severe hearing impairment of preschool age because child still at the stage of holophrase, but has shown the development of syntactic role of Indonesian language as well as children at the telegraphic stage, as evidenced by the acquisition of syntactic roles meaning 'quantity' and 'existence/place '.
\end{abstract}

Keywords-development; syntactic roles; deviation; severe hearing impairment

\section{INTRODUCTION}

Studies dealing with the syntactic development of deaf children have been done, but no one has focused on syntactic roles. Some of the existing studies focus on other objects of study, such as the development of word counts in sentences (Szagun, 2000), sentence patterns (Fujiyoshi, et al., 2012), syntactic categories (Leroy, Parisse, \& Maillart, 2013), relative clauses (Friedmann \& Vogrodsky, 2004), and syntactic construction complex (Teymouri, Daneshmandan, Hemmati \& Soleimani, 2014). Research on the syntactic role that has been done using the subject of research that children can hear (Darjowidjoyo, 2000). In fact, the characteristics of children who can hear differently from children with hearing impairment.

Due to their limitations, deaf children tend to be difficult or cannot utter full sentences. Sometimes the words spoken by a deaf child are only words, even syllables. Therefore, it is necessary to understand the syntactic role in order to know the meaning of the sentence that is spoken.

Based on research on the development of the syntactic role of deaf children obtained important information, namely the sequence of acquisition of syntactic role and its relationship with the cognitive development of children with hearing impairment. In addition, information about irregularities that occur in the development of the syntactic role of children with hearing impairment.

According to Kridalaksana (2008), "deviation is a common name of speech that is inconsistent with the norm" (p. 150). The meaning of the norm is "the pattern or trait that is considered most common in the situation of a language".

The deviation cannot be considered an error, but part of language acquisition. According to Brown (2007), the outcome of each stage of child language development is a recognized system. It is not an inappropriately reduced process of structure, but a systematic development at every stage. Through the generated language, a child will continue to test a series of hypotheses. The hypothesis will be revised, reestablished, even abandoned (p. 29). Therefore, through the development of the syntactic role of deaf children can be known cognitive development.

\section{LITERATURE REVIEW}

Syntactic development is a sequence of acquisitions that sees interrelationships to form sentences. Based on the object of syntactic study, syntactic development can be investigated from (1) syntactic structures that include functions, categories, and roles; (2) syntactic units of words, phrases, clauses, and sentences; (3) syntactically related matters, such as mode, aspect, period, modality, focus and diathesis; (4) the transformation includes the outer structure and internal structure; (5) generative universal grammar, principles, and parameters (O'Grady, 2000, p. 167; Harley, 2008, pp. 36-42; Chaer, 2007, p. 206).

The syntactic role is the meaning of the filler element in the clause (Chaer, 2007, p. 208). According to Verhaar (2008, p. 167), the syntactic role refers to the meaning of the functional element filler of the sentence. Syntactic roles relate to the semantic aspects of the verb roles as well as to the grammatical meanings. Syntactic roles are rooted in verbs that refer to the role of the predicate. Because natural Indonesian predicates are not always verbs, other types of words, such as 
nouns, adjectives, and numerals. The verb is associated with an event. Examples of syntactic roles: actors, actions (active or passive), goals, time, and so on.

In this study, the development of a syntactic role is applied to children with hearing impairment. Kirk (2009) states that a deaf child is a person who lacks or loses the ability to hear both in part and in whole (p. 27). According to the Clinical Evaluation of Language Fundamentals (in Marschark \& Spencer, 2011, p. 249), the degree of hearing impairment consists of (1) mild (25-40 dB HL), (2) moderate (40-70 dB $\mathrm{HL}$ ), (3) weight (70-90 dB HL), (4) severe (95 dB HL or harder).

\section{METHOD}

This study was conducted longitudinally in three subjects. Determination of the number of subjects based on Ingram's (1992) opinion that the three subjects are minimal absolute numbers. Subjects were severe preschooler pre-school age $(5 ; 0)$ students attending group A TKLB-B (nursery school for students with special needs) and using the first language in Indonesian. The data used is the speech of research subjects that can provide information on the development of the syntactic role of Indonesian children severe hearing impairment of preschool age. The word in question is a sentence as well as a word or syllable referred to as a sentence. Data is taken when the child is in the class, at home, or playing.

Data collection uses four techniques, namely observation, fishing, record, and record. To be able to collect data used instrument data collection in the form of verbal media supported by reliable media and visual media. The procedures used are (1) establishing the time of data collection, (2) participatory and nonparticipative observation, (3) transcribing the data obtained, (4) validating the data, and (5) storing the collected data.

Data were analyzed with three techniques, namely sort, reverse, and connect techniques. Instruments used for data analysis, ie tables. The procedures used are (1) classifying data, (2) presenting data, (3) interpreting data, (4) summarizing, and (5) validating the findings. At the time of classification used the technique of divide by instrument table. Through the classification, all data that has been included in the table can be viewed as a whole making it easier to review the data needed. The next step, which gives meaning is done by connecting data with each other.

\section{RESUlt AND DisCUSSION}

Data collection was conducted for 31 weeks or 31 periods. In this study, one week termed one period.

Based on the research result obtained two information, that is the development of syntactic role and existence of deviation of syntactic role development. Here's an explanation of both.

\section{A. The Development of Syntactic Roles}

The development of the syntactic roles of the three research subjects is almost the same although obtained at different times. The development of syntactic roles in the three subjects is seen when subjects produce syllables or words intended to express sentences. Discussion of the development of syntactic roles of the three subjects as follows.

\section{1) The development of syntactic roles subject 1}

The development of syntactic role in subject 1 begins in period 2 when subject 1 produces a syllable only, ie [ya] which means Telinga. In the sentence, the word is a filler element $\mathrm{P}$ meaning 'identifier'. The development of syntactic roles is followed by subsequent developments. In a complete sequence the acquisition of the $\mathrm{S} 1$ syntactic role, is (a) $\mathrm{P}$ means 'identifier', (b) S means 'experience' and 'actor', (c) P means 'action', (d) P means ' situation ', (e) O means 'sufferer', (f) P means 'existence/place', (g) K means 'existence/place', (h) P means 'quantity', and (i) Pel meaning 'sufferer'. The development or sequence of Indonesian syntactic roles resulting from $\mathrm{S} 1$ appears in the following table.

TABLE I. THE DEVELOPMENT OF SYNTACTIC ROLES SUBJECT 1

\begin{tabular}{|c|c|c|c|c|}
\hline \multirow{3}{*}{$\begin{array}{c}\text { Per } \\
2\end{array}$} & \multicolumn{4}{|c|}{ The Development of Syntactic Roles S1 } \\
\hline & \multicolumn{2}{|c|}{ Sentence Generated } & \multirow{2}{*}{$\begin{array}{l}\begin{array}{c}\text { Sentence that } \\
\text { Means }\end{array} \\
\text { Ini telinga } \\
\text { Ini bapak } \\
\end{array}$} & \multirow{2}{*}{$\begin{array}{c}\text { Syntactic Roles } \\
\text { P means 'identifier' }\end{array}$} \\
\hline & $\begin{array}{l}\text { [ya] } \\
{[\mathrm{pa}]}\end{array}$ & $\begin{array}{l}\text { Telinga } \\
\text { Bapak }\end{array}$ & & \\
\hline \multirow[t]{2}{*}{5} & [atə] & Adik & Adik makan & S means 'actor' \\
\hline & [уаә] & Coklat & Coklat enak & S means 'experience' \\
\hline 9 & [upu] & Bubuk & Tegar bubuk & P means 'action' \\
\hline 11 & [eat?] & Hitam & $\begin{array}{l}\text { Warnanya } \\
\text { hitam }\end{array}$ & P means 'situation' \\
\hline 13 & [təyo] & Telur & $\begin{array}{l}\text { Ziani makan } \\
\text { telur }\end{array}$ & O means 'sufferer', \\
\hline 15 & $\begin{array}{l}\text { [meya] } \\
\text { (Gesturing } \\
\text { di-) }\end{array}$ & (di) Meja & $\begin{array}{l}\text { Coklatnya di } \\
\text { meja }\end{array}$ & $\begin{array}{l}\text { P means } \\
\text { 'existence/place' }\end{array}$ \\
\hline 18 & $\begin{array}{l}\text { [ute] } \\
\text { (Gesturing } \\
\text { di-) }\end{array}$ & (di) Kursi & $\begin{array}{l}\text { Cinta duduk } \\
\text { di kursi }\end{array}$ & $\begin{array}{l}\text { K means } \\
\text { 'existence/place' }\end{array}$ \\
\hline 17 & [atu] & Satu & Apelnya satu & P means 'quantity' \\
\hline 20 & [obat] & Obat & $\begin{array}{l}\text { Hidungnya } \\
\text { diberi obat }\end{array}$ & Pel means 'sufferer' \\
\hline
\end{tabular}

\section{2) The development of syntactic roles subject 2}

The development of syntactic role in subject 2 occurs in period 3 when subject 2 produces a syllable only is [ya] meaning Mata. In the sentence, the word is a filler element $\mathrm{P}$ meaning 'identifier'. The development of syntactic roles is followed by subsequent developments. The complete sequence of the syntactic role of $\mathrm{S} 2$, is (a) P means 'identifier', (b) S means 'experience', (c) S means 'actor', (d) P means 'action', (e) P means 'situation', (f) $\mathrm{O}$ means 'sufferer', (g) $\mathrm{P}$ means 'existence/place', (h) K means 'existence/place' and $\mathrm{P}$ means 'quantity', and (i) Pel meaning 'sufferer'. The development or sequence of the syntactic role of Indonesian generated by S2 is shown in the following table. 
TABLE II. THE DEVELOPMENT OF SYNTACTIC ROLES SUBJECT 2

\begin{tabular}{|c|c|c|c|c|}
\hline \multirow[b]{2}{*}{ Per } & \multicolumn{4}{|c|}{ The Development of Syntactic Roles S2 } \\
\hline & \multicolumn{2}{|c|}{ Sentence Generated } & \multirow{2}{*}{$\begin{array}{l}\text { Sentence that } \\
\text { Means } \\
\text { Ini mata } \\
\text { Ini bapak }\end{array}$} & \multirow{2}{*}{$\begin{array}{c}\text { Syntactic Roles } \\
\text { P means 'identifier' }\end{array}$} \\
\hline 3 & $\begin{array}{l}\text { [ya] } \\
{[\mathrm{pa}]} \\
\end{array}$ & $\begin{array}{l}\text { Mata } \\
\text { Bapak }\end{array}$ & & \\
\hline 6 & [atə] & Adik & Adik makan & S means 'actor' \\
\hline 9 & [уаә] & Coklat & $\begin{array}{l}\text { Enak } \\
\text { coklatnya }\end{array}$ & S means 'experience' \\
\hline 11 & $\begin{array}{l}\text { [yaə] } \\
\text { [mpate] }\end{array}$ & $\begin{array}{l}\text { Makan } \\
\text { Mandi }\end{array}$ & $\begin{array}{l}\text { Makan } \\
\text { Nyam-nyam } \\
\text { Ziani mandi }\end{array}$ & P means 'action' \\
\hline 13 & [eya] & Merah & $\begin{array}{l}\text { Lampunya } \\
\text { merah }\end{array}$ & P means ‘situation’ \\
\hline 16 & [mpe] & $\mathrm{Mi}$ & $\begin{array}{l}\text { Ziani makan } \\
\text { mi }\end{array}$ & O means 'sufferer', \\
\hline 20 & $\begin{array}{l}\text { ta] } \\
\text { (Gesturing } \\
\text { di-) }\end{array}$ & $\begin{array}{l}\text { (di) } \\
\text { Tas }\end{array}$ & $\begin{array}{l}\text { Pensilnya } \\
\text { di tas }\end{array}$ & P means 'existence/place' \\
\hline 22 & $\begin{array}{l}\text { [atu// ta] } \\
\text { (Gesturing } \\
\text { di-) }\end{array}$ & $\begin{array}{l}\text { Masuk } \\
\text { (di) } \\
\text { Tas }\end{array}$ & $\begin{array}{l}\text { Krayonnya } \\
\text { dimasukkan } \\
\text { (di) tas }\end{array}$ & $\begin{array}{l}\text { K means } \\
\text { 'existence/place' }\end{array}$ \\
\hline & [uwa] & Dua & $\begin{array}{l}\text { Sepatunya } \\
\text { dua }\end{array}$ & P means 'quantity' \\
\hline 24 & [obat] & Obat & $\begin{array}{l}\text { Kakinya } \\
\text { diberi obat }\end{array}$ & Pel means 'sufferer' \\
\hline
\end{tabular}

\section{3) The development of syntactic roles subject 3}

The development of syntactic role in subject 3 occurs in period 3 when subject 3 produces a syllable only, ie [a] which means Mata. In the sentence, the word is a filler element $\mathrm{P}$ meaning 'identifier'. The development of syntactic roles is followed by subsequent developments. The complete sequence of S3 derived roles, ie (a) P means 'identifier', (b) S means 'experience', (c) S means 'actor', (d) P means 'action', (e) P means 'situation', (f) $\mathrm{O}$ means 'sufferer', (g) $\mathrm{P}$ means 'existence/place', (h) K means 'existence/place', (i) P means 'quantity', (j) Pel meaning 'sufferer'. The development or sequence of the syntactic role of Indonesian language produced by S3 is shown in the following table.

TABLE III. THE DEVELOPMENT OF SYNTACTIC ROLES SUBJECT 3

\begin{tabular}{|c|c|c|c|c|}
\hline \multirow[b]{2}{*}{ Per } & \multicolumn{4}{|c|}{ Development of Syntactic Roles S3 } \\
\hline & \multicolumn{2}{|c|}{ Sentence Generated } & $\begin{array}{l}\text { Sentence that } \\
\text { Means }\end{array}$ & Syntactic Roles \\
\hline 3 & [a] & Mata & Ini mata & P means 'identifier' \\
\hline 7 & {$[\mathrm{u}]$} & Tikus & Tikus lari & S means 'actor' \\
\hline 10 & [aə] & Tangan & $\begin{array}{l}\text { Tangannya } \\
\text { kotor }\end{array}$ & S means 'experience' \\
\hline 13 & [aə] & Makan & Tegar makan & P means 'action' \\
\hline 17 & [pue] & $\begin{array}{l}\text { Putih } \\
\text { Biru }\end{array}$ & $\begin{array}{l}\text { Warnanya } \\
\text { putih } \\
\text { Warnanya } \\
\text { biru }\end{array}$ & P means 'situation' \\
\hline 20 & $\begin{array}{l}\text { [oyo] } \\
\text { [bato] }\end{array}$ & $\begin{array}{l}\text { Oreo } \\
\text { Bakso }\end{array}$ & $\begin{array}{l}\text { Cinta makan } \\
\text { oreo } \\
\text { Tegar makan } \\
\text { bakso }\end{array}$ & O means 'sufferer', \\
\hline 22 & $\begin{array}{l}\text { [taə] } \\
\text { [uma] } \\
\text { (Gesturing } \\
\text { di-) }\end{array}$ & $\begin{array}{l}\text { (di) Air } \\
\text { (di) } \\
\text { Rumah }\end{array}$ & $\begin{array}{l}\text { Ikannya } \\
\text { di air } \\
\text { Adik di } \\
\text { rumah }\end{array}$ & P means 'existence/place' \\
\hline 24 & $\begin{array}{l}\text { [apa] } \\
\text { (Gesturing }\end{array}$ & $\begin{array}{l}\text { (di) } \\
\text { Tempat }\end{array}$ & $\begin{array}{l}\text { Bungskusnya } \\
\text { dibuang (di) }\end{array}$ & $\begin{array}{l}\text { K means } \\
\text { 'existence/place' }\end{array}$ \\
\hline
\end{tabular}

\begin{tabular}{|c|l|l|l|l|}
\hline \multirow{2}{*}{ Per } & \multicolumn{4}{|c|}{ Development of Syntactic Roles S3 } \\
\cline { 2 - 5 } & \multicolumn{2}{|c|}{ Sentence Generated } & $\begin{array}{l}\text { Sentence that } \\
\text { Means }\end{array}$ & \multicolumn{1}{c|}{ Syntactic Roles } \\
\hline & di-) & sampah & $\begin{array}{l}\text { tempat } \\
\text { sampah }\end{array}$ & \\
\hline 26 & {$[$ uwa] } & Dua & Rodanya dua & P means 'quantity' \\
\hline 29 & {$[$ yaal $]$} & Gelang & $\begin{array}{l}\text { Tangannya } \\
\text { diberi gelang }\end{array}$ & Pel means 'sufferer' \\
\hline
\end{tabular}

Overall, the development of the syntactic role of Indonesian subjects in three subjects can be seen in the following table.

TABLE IV. THE DEVELOPMENT OF INDONESIAN SYNTACTIC ROLE OF RESEARCH THREE SUBJECTS

\begin{tabular}{|c|c|c|c|}
\hline \multirow[t]{2}{*}{ No } & \multicolumn{3}{|c|}{ Development of Syntactic Roles } \\
\hline & $S 1$ & $S 2$ & $S 3$ \\
\hline 1 & P means 'identifier' & P means 'identifier' & P means 'identifier' \\
\hline 2 & $\begin{array}{l}\text { S means 'actor' } \\
\text { S means 'experience' }\end{array}$ & S means 'actor' & S means 'actor' \\
\hline 3 & P means 'action' & $\begin{array}{l}\text { S means } \\
\text { 'experience' }\end{array}$ & $\begin{array}{l}\text { S means } \\
\text { 'experience' }\end{array}$ \\
\hline 4 & P means 'situation' & P means 'action' & P means 'action' \\
\hline 5 & O means 'sufferer', & P means 'situation' & P means 'situation' \\
\hline 6 & $\begin{array}{l}\text { P means } \\
\text { 'existence/place' }\end{array}$ & O means 'sufferer', & O means 'sufferer', \\
\hline 7 & $\begin{array}{l}\text { K means } \\
\text { 'existence/place' }\end{array}$ & $\begin{array}{l}\text { P means } \\
\text { 'existence/place' }\end{array}$ & $\begin{array}{l}\text { P means } \\
\text { 'existence/place' }\end{array}$ \\
\hline 8 & P means 'quantity' & $\begin{array}{l}\text { K means } \\
\text { 'existence/place' } \\
\text { P means 'quantity' }\end{array}$ & $\begin{array}{l}\text { K means } \\
\text { 'existence/place' }\end{array}$ \\
\hline 9 & Pel means 'sufferer' & Pel means 'sufferer' & P means 'quantity' \\
\hline 10 & & & Pel means 'sufferer' \\
\hline
\end{tabular}

The development of the syntactic role of all three subjects is clear, although S1 and S2 directly acquire two syntactic roles. In period 2, S1 obtained S which means 'offender' and 'experience'. In period 8, S2 obtains $\mathrm{K}$ meaning 'existence/place' and $\mathrm{P}$ which means 'quantity'. Through the concept of Ingram (1992, p. 22) which states that decisions can be made by looking at two subjects, the development of the syntactic role of the three Indonesian subjects of study can be determined.

Until the period 31, the development or sequence of syntactic roles in Indonesian children's severe hearing impairment of preschool age in the form of (a) $\mathrm{P}$ means 'identifier', (b) S means 'experience', (c) S means 'actor', (d) P means 'action', (e) P means 'situation', (f) O means 'sufferer', (g) P means 'existence/place', (h) K means 'existence/place', (i) P means 'quantity', (j) Pel meaning 'sufferer'.

Based on information from the development of the syntactic role of the three research subjects obtained information, namely, there is a deviation in the development of the syntactic role of children with hearing impairment. Subjects aged 5;0 still produce sentences consisting of one word, even one syllable. Therefore, the subjects are still at the stage of the holophrase.

According to Steinberg, et al. (2001, pp. 3-27) and Darjowidjoyo (2012, p. 246), at the stage of the holophrase, 
the resulting sentence is a one-word sentence for all desired intentions. Typically, the spoken word is the word deemed most important by the child to express intent.

According to Winarsih (2007), in special education, hearing impaired children understand language symbols or give names to represent objects, activities, events, specific feelings, and prevailing language structures and systems. Thus, deaf children enter the linguistic stage at the time of entering school. When a child who is able to hear around the age of 5;0 has reached the pace or first phase of perfect language acquisition, in children with hearing impairment, the new paralinguistics occurs at the age of 12 years. It only happens when children and parents follow early guidance and intervention programs (pp. 36-37).

When examined, the first syntactic role obtained by deaf children, namely $\mathrm{P}$ means 'identifier' and then $\mathrm{S}$ means 'experience'. This means that the deaf child is still in the stage of recognition on objects or concrete objects. Along with its cognitive development, the child obtains P means 'action' and $\mathrm{P}$ means 'situation'. It provides information on the cognitive development of children. Things that are concrete, visible, can be held, and there are around the child, first obtained. In this case, the principle here and now can be a reference. Syntactic roles mean 'action' and 'situation' refer to more abstract things.

The statement was corroborated by Rusli (2009) who conducted research on the acquisition of Indonesian vocabulary deaf children aged 7-9. Rusli explains that the acquisition of vocabulary in learners is still limited to nouns, verbs, adjectives, and numerals. Implicitly, the first three sequences, namely nouns, verbs, and adjectives have similarities to the results of this study.

\section{B. Deviation of Syntactic Role Development}

In addition to information about the development of syntactic roles and cognitive development of children with hearing impairment, the results of the study also provide information about the deviation of synthetic role development of children with hearing impairment. Subjects still at the stage of the holophrase have shown the development of a syntactic role that differs from that of children who are in the stage of holophrase in general, that is, they have not received syntactic roles of 'quantity' and 'existence/place'.

In research Rusli (2009) who use the subject of research deaf children aged 7-9 years also states the acquisition of vocabulary in the form of numerals after the adjective. The difference between this study and Rusli, namely the generation of numerals, whereas in this study, after obtaining $\mathrm{P}$ means 'situation', the subjects did not get $\mathrm{P}$ which means 'quantity', but $\mathrm{P}$ and $\mathrm{K}$ meaning 'existence/place'. Gregory, Knight, Mc Cracken, Powers, \& Watson (1998) who also conducted research on the deaf children say almost the same thing, the deaf children begin to produce words that refer to people, objects, and locations that are concrete (p. 60).

The resulting syntactic role of 'quantity' and 'existence/place' by the study subjects is interesting because the three subjects of this study are still at the stage of the holophrase. 'Quantity' and 'existence/place'are usually obtained at the telegraphic stage. This is in line with
Steinberg's, et al. (2001) statement that children at the telegraphic stage at around age 2;0 have abilities related to the identifier, recipient, experience, existence, place, equality, difference, and quantity. Children already have the ability to produce the word task (p. 10).

Syntactic roles mean 'existence/place' produced by the subjects of imperfect research. Research subjects simply state where something is located, whereas the prepositions of the preposition word are not obtained because the subject of the study only uses sign language. Cues are used because research subjects still have the ability to produce single word sentences, whereas to produce a syntactic role meaning 'existence' takes two words. Therefore, the study subjects used sign language.

\section{V.CONCLUSION}

The development of the syntactic roles of the three subjects research is almost the same although obtained at different times.

Based on the results of data analysis found (1) the development or sequence of syntactic role derivation of Indonesian children severe hearing impairment of preschool age describes his cognitive development include (a) $\mathrm{P}$ means 'identifier', (b) S means 'experience', (c) S means 'actor', (d) P means 'action', (e) P means 'situation', (f) O means 'sufferer', (h) P means 'existence/place', (h) K means 'existence/place', (i) P means 'quantity', (j) Pel means 'sufferer'; (2) there is a deviation in the development of the syntactic role of Indonesian children severe hearing impairment of preschool age because child still at the stage of holophrase, but has shown the development of syntactic role of Indonesian language as well as children at the telegraphic stage, as evidenced by the acquisition of syntactic roles meaning 'quantity' and 'existence/place '.

\section{Acknowledgment}

The researchers would like to thank the Head of Indonesian Language and Literature Studies Program, the Dean of the Faculty of Teacher Training and Education, and the Rector of PGRI University Adi Buana Surabaya who always gave moral and material support to the progress of the lecturers.

\section{References}

Chaer, A. (2007). Linguistik umum. Jakarta: Rineka Cipta.

Brown, D. H. (2007). Principles of language learning and teaching. New York: Pearson Education.

Dardjowidjojo, S. (2000). Echa: kisah pemerolehan bahasa anak Indonesia. Jakarta: PT Gramedia Widiasarana Indonesia.

Dardjowidjojo, S. (2012). Psikolinguistik: pengantar pemahaman bahasa manusia. Jakarta: Yayasan Obor Indonesia.

Friedmann, N. \& Vogrodsky, R. (2004) The acquisition of relative clause comprehension in Hebrew: a study of SLI and normal development. Journal of Child Language, 31(2004), 661—681. doi: 10.1017/ S0305000904006269. 
Fujiyoshi, A., Fukushima, K., Taguchi, T., Omori, K., Kasai, N., Nishio, S., Shiroma, M. (2012). Syntactic development in Japanese hearing-impaired children. Annals of Otology, Rhinology, and Laryngology, 121(4), Suppl 202: 28-34.

Gregory, S., Knight, P., Mc Cracken, W., Powers, S., \& Watson, L. (1998). Issues in deaf education. London: David Fulton Publishers

Harley, T. A. (2008). Psychology of language. Canada: Psychology Press.

Ingram, D. (1992). First language acquisition: Method, description, and explanation. Cambridge: Cambridge University Press.

Kirk, S. Gallagher, J. J., Coleman, M. R., Anastasiow, N. (2009). Educating exceptional children. Belmond: Wadsworth Cengage Learning.

Kridalaksana, H. (2008). Kamus linguistik. Jakarta: PT Gramedia Pustaka Tama.

Leroy, S., Parisse, C., \& Maillart, C. (2013). The influence of the frequency of functional markers on repetitive imitation of syntactic constructions in children with specific language impairment, from their own language productions. Clinical Linguistics \& Phonetics, 27(6-7): 508-520, doi: 10.3109/02699206.2013. 787546.

Marschark, M. \& Spencer, P. E. (2011). The Oxford handbook of deaf studies, language, and education. Oxford: Oxford University Press.
O'Grady, W. (2000). Syntax: the analysis of sentences structure. In O'Grady, W. \& Archibald, J. (Ed.), Contemporary Linguistics: An introduction (pp. 167-223). Canada: Pearson Education Canadian Inc.

Steinberg, D. D., Nagata, H., \& Aline, D. P. (2001). Psycholinguistics language mind and world. London: Longman.

Szagun, G. (2000). The acquisition of grammatical and lexical structures in children with Cochlear. Journal of Audiology and Neurotology, 5(1), 39-47.

Teymouri, R., Daneshmandan, N., Hemmati, S., \& Soleimani, F. (2014). Perception development of complex syntactic construction in children with hearing impairment Journal Iranian Rehabilitation, 12. (22), 11-16.

Verhaar, J.W.M. (2008). Asas-asas linguistik umum. Yoyakarta: Gajah Mada University Press. 